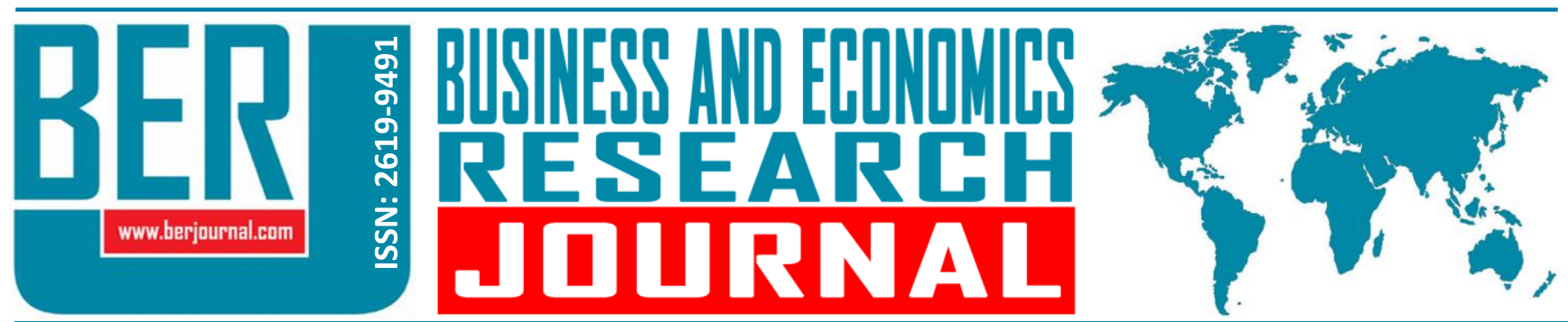

Business and Economics Research Journal Vol. 9, No. 3, 2018, pp. 589-603 doi: 10.20409/berj.2018.125

\section{Muhasebe Standartları Bankalarda İşletme Performansını ve Finansal Tablo Manipülasyonunu Etkiler mi?}

Anahtar Sözcükler: Finansal Tablo Manipülasyonu, Kurumsal Yönetim, İşletme PerformansI, IFRS

JEL: G14, G30, G34, M40, M41

$\begin{array}{ll}\text { Geliş } & : \text { 11 Nisan } 2018 \\ \text { Düzeltme } & : 23 \text { Mayıs } 2018 \\ \text { Kabul } & : \text { 06 Haziran } 2018 \\ \text { Tür } & : \text { Araştırma }\end{array}$

Keywords: Financial Statement Manipulation, Corporate Governance, Firm Performance, International Financial Reporting Standards

JEL: G14, G30, G34, M40, M41

\begin{abstract}
Financial statement manipulation has been well-rounded analyzed in both finance and unting literature as it is important to determine whether firms could affect both performan and accounting standards. The purpose of this study is to examine cases of financial reporting manipulations which were subject to published enforcement actions by the Securities Exchange Commission (SEC), Securities Class Action Clearinghouse (SCAC), Accounting and Auditing Enforcement Releases (AAERs) and General Accounting Office (GAO) between 1996 and 2014 for reasons of alleged financial misstatements in the USA. Therefore, this study will provide to examine the relationship between bank performance and financial statement manipulations in the accounting standards. More importantly, although financial misconduct such as financial reporting manipulation is an emerging topic of great importance, a comprehensive literature review of the subject has yet to be carried out in terms of accounting standards. In this context, this study focuses on financial reporting manipulation within the context of International Financial Reporting Standards (IFRS). This study is contributed to the literature by examining the impact of financial reporting manipulation within the same or different systems of accounting standards on bank financial reporting. Findings suggest that banks that manipulate financial statements increase their operating profitability and productivity as a measure of financial performance used in the IFRS.
\end{abstract}

a Assoc. Prof., PhD., Ankara Yıldırım Beyazıt University, Business School, Department of Management, Ankara Turkiye, akgun.aliihsan@gmail.com (ORCID ID: 0000-0002-6441-8196) 


\section{Giriş}

İşletmelerde uluslararası finansal ilişkilerin artması sonucunda dünya finansal piyasalarının bütünleşmesine ve bu piyasaların küreselleşmesine yol açmıştır. Küreselleşen piyasalara bağlı olarak işletmelerde finansal raporlamanın öneminin artmasına ve uluslararası normlara bağlanmasını ortaya çıkarmıştır (Akgün, 2012: 43). Böylece, dünyada hızlı bir biçimde artan finansal raporlama standartları intiyacını karşılamak amacıyla Uluslararası Muhasebe Standartları Kurulu (IASB) tarafından Uluslararası Muhasebe Standartları (IAS) ve Uluslararası Finansal Raporlama Standartları (IFRS) yayınlanmıştır. IASB tarafından yapılan finansal raporlama standartlarına yönelik çalışmalarının yanında Amerikan Muhasebe Standartları Kurulu (FASB)'nun da US GAAP standartları bulunmaktadır (Akgün, 2011: 40). Bu standartlardan IASB'nın yayınladığı standartların ilke bazlı standartlar olması ve US GAAP standartlarının ise kural bazlı standart olması her iki standardı birbirinden ayıran temel farklılığı göstermektedir (Akgün, 2012b: 8).

Finansal piyasalardaki küreselleşme ve küreselleşmeye bağlı olarak işletmelerin büyümesi ve iletişimin hızlanması ile birlikte, işletmelerin işlem sayısı artmış ve işlemler karmaşık hale gelmiştir. Bu durum, işletme yönetiminde profesyonelleşme olgusunu ortaya çıkarmış ve işletme ile ilgili karar alma durumunda olan finansal tablo kullanıcılarının güvenilir bilgiye olan ihtiyacını artırmıştır. Böylece, kurumsallaşmaya bağı olarak işletmeler ile ilgili en önemli bilgi kaynağı olan finansal tabloların güvenilirliği önemli hale gelmiştir. Özellikle, işletme yönetimi tarafından muhasebe politikalarındaki esnekliklerden yararlanılması veya bazen bunun dışına çıkılarak finansal tabloların gerçeğe aykırı şekilde sunulması, başka bir ifadeyle finansal tabloların manipüle edilmesi finansal tablolara olan güveni zayıflatmıştır.

Bununla birlikte, muhasebe standartlarında yöneticilerin kararına bırakan uygulamaların etkisinin olması, gelecekte işletmeye olan nakit akışlarını da etkiler hale gelmiştir. Muhasebe standartlarında değişime yol açan faktörlerin başında; vergiler, düzenleyici kuruluşların tutumları, üst yönetime verilen hisse teşvikleri, politik maliyetler ve diğer maliyetler gelmektedir. Ayrıca, muhasebe standartlarında yöneticilerin kararına bırakılan uygulamaların olması, hissedarların firma değeri ve performansına olan ilgisini artırmaktadır. Böylece, muhasebe prosedür ve politikalarındaki değişiklik, hisse senedi fiyatlarını değiştirmeye yol açarak doğrudan yöneticilerin spekülatif olarak finansal tablo manipülasyonuna yol açmalarına teşvik etmektedir (Watts ve Zimmerman, 1978: 112-115).

Finansal tablo manipülasyonu, işletmelerin finansal durumlarının gerçeğe uygun şekilde gösterilmesini engellemekte ve yöneticilerin yanlış finansal kararlar alınmasına neden olmaktadır. Bunun en iyi örneği, $A B D$ ve Dünya genelinde yaşanan finansal raporlama skandallarında ortaya çıkmıştır. Özellikle, ABD'de 2000'li yıllarda Enron, WorldCom, Parmalat gibi şirketlerin finansal tablolarında manipülasyon yapıldığının ortaya çıkması ile birlikte söz konusu işletmeler önemli güçlükle karşı karşıya kalmışlardır. Ayrıca, söz konusu işletmelerin finansal tablolarının manipüle edildiğini duyan sermaye sahiplerinin ekonomik sisteme olan güvenlerinin azalması sonucunda, ekonomik sistemin tamamı bu gelişmelerden olumsuz etkilenmiştir. Söz konusu bu güçlüğün çözülebilmesi ve sermaye piyasalarına olan güvenin yeniden kazanılması için finansal sisteme ilişkin düzenleyici otoriteler tarafından düzenlemeler yapılmıştır. Bu bağlamda yapılan düzenlemeler incelendiğinde, finansal tablo manipülasyonunun önlenmesinin iyi bir kurumsal yönetim sisteminden geçtiği yönünde bir kanının oluştuğu ortaya çıkmaktadır. Ancak, literatürde özellikle banka işletmelerinde, finansal tablo manipülasyonunun önlenmesinde ve finansal tabloların güvenilirliğinin arttırılmasında kurumsal yönetiminin etkin rolü olan muhasebe ve finansal raporlama standartlarının etkisini ölçmeye yönelik yeterli bir çalışma bulunmamaktadır.

Finansal tablo manipülasyonu ile muhasebe ve finansal raporlama standartlarının arasındaki direkt ilişkiyi gösteren literatür çalışmasına sınırı sayıda rastlanmaktadır. Dye (2002) çalışmasında muhasebe standartları ve manipülasyon arasındaki ilişkiye yer vermiştir. Birçok çalışmada, işletme personeli dışından bağımsız CEO çalıştırarak finansal raporlamadaki yanlışlıkların nasıl azaltılacağı ve performans manipülasyonun rolü üzerinde durulmuştur (Maggi ve Rodriguez-Clare, 1995; Dutta ve Gigler, 2002; Crocker ve Slemrod, 2007). Bazı çalışmalar ise, muhasebede hile araştırmalarına odaklanarak, finansal tablolardaki maddi hataları önlemek için denetçinin yükümlülüğünü incelemiştir (Dellaportas, 2013). Bu çalışmada ise, 
finansal tablo hileleri, manipülasyon ve bağımsız denetimden geçmiş finansal tablolarda denetçi raporlarına yansıyan olumsuzluklar ile muhasebe standartları arasındaki ilişkinin ortaya konulması amaçlanmıştır.

Ayrıca, literatürdeki yapılan bazı çalışmalar, muhasebe usulsüzlükleri ve yöneticilerin prim teşvikleri arasındaki ilişkiyi incelemiştir (Efendi vd., 2007; Bergstresser ve Phillipon 2006; Harris ve Bromiley, 2007). Örneğin, Harris ve Bromiley (2007) çalışmalarında, muhasebe raporlarında yanlış beyan ile yönetici tazminatları arasında pozitif bir ilişki olduğunu tespit etmiştir. Ancak, az sayıda çalışma (O'Connor vd., 2006; Burns ve Kedia , 2006), muhasebe manipülasyonu azaltmak için yönetici teşvik primi yerine şirket hisselerinden yöneticiye pay vermeyi alternatif bir olasılık olduğunu ifade etmişlerdir. Ayrıca, Freeman (2010) yaptığı çalışmasında, finansal tablo manipülasyonu dalgasının arkasındaki kararların çoğu, işletmelerde var olan ve büyük primler ile yakından ilişkili olduğu sonucuna varmıştır. Harris ve Bromiley (2006), muhasebe manipülasyonlarının sıklığı ile CEO teşvik tazminatları arasında pozitif bir ilişki bulurken, Baber et al. (2009) benzer bir istatistiksel bir ilişki bulamamıştır.

Bu çalışmada, bankalarının performans göstergeleri olarak varlık karlılığı (ROA), öz sermaye karlılı̆ı (ROE) ve aktif devir hızı oranı (ATO) kullanılmıştır. ROA, varlıklardan gelir elde etmede işletme yönetiminin ne kadar etkili olduğunun tasvirini oluşturduğundan, bankaların finansal performansı ve yönetsel etkinliğinin bir göstergesi niteliğindedir. Ayrıca, bu oran finansal literatürde banka performansının temel ve en sık kullanılan oranıdır. Dietrich ve Wanzenried (2011) çalışmalarında, ROE'nin performans göstergesi olarak finansal araştırmalarda yaygın olarak kullanılmasına rağmen, bu oranın daha düşük bir kaldıraç oranı veya daha yüksek öz sermayesi olan bankaların daha yüksek bir ROA'ya sahip olduklarını gözlemlemişlerdir.

Ayrıca, ROA bir şirketin tüm kaynaklarından net gelir elde etmede etkinliğinin de göstergesidir. Dolayısıyla, daha yüksek bir ROA, şirketin kaynaklarını kullanmada daha verimli ve etkin olduğunu göstermektedir. Bu çalışmada kullanılan performans ölçütlerinden bir diğeri ROE olup, ROE ise, bir şirketin net gelirinin, yatırım yapılan veya bilançoda bulunan toplam öz kaynak tutarına bölünmesiyle elde edilen finansal bir orandır. Öz kaynak kârlıı̆̆ı yüksek bir işletmenin, nakit yaratma yeteneğinin daha yüksek olduğu söylenebilir. Dolayısıyla, ROE arttıkça, şirketin kâr yaratma açısından daha iyi olduğu ve böylece yönetimin hissedar sermayesini kullanmada daha etkili olduğu söylenebilir (Akgün ve Şamiloğlu, 2017: 456). ATO ise işletmenin gelir oluşturmasında kullanılan varlıkların etkinliğini göstermektedir. Dolayısıyla, varlıkların edinilmesindeki yüksek satış gelirleri, bu varlıkların tahsisinde ne kadar etkin olduğunu gösterir. Böylece, genellikle ATO performans göstergesi ile işletmenin performansına pozitif bir etkisi olduğu beklenmektedir (Mitra \& Adhikary, 2017: 112).

Bu çalışmada, finansal tablo manipülasyonu ile farklı muhasebe ve finansal raporlama standardının kullanıması banka işletmelerinin performansını etkileyip etkilemediği analiz edilerek literatüre katkı sağlanacaktır. Çalışmada, finansal tablo manipülasyonu ile IFRS uyumu arasındaki ilişki incelenmekte, işletmelerin kullandığı finansal raporlama standardının finansal tablo manipülasyonunu azaltıp ya da azaltmaması irdelenecektir. Çalışmada, öncelikle, finansal tablo manipülasyonu, kurumsal yönetim ve muhasebe standartlarına ilişkin kavramsal çerçeve incelenecektir. Literatür araştırmasında ise hem finansal tablo manipülasyonuna yönelik yapılan araştırmalara yer verildikten sonra araştırmanın hipotezleri, araştırmada ele alınan yöntem ve araştırmanın bulgularına yer verilmiştir.

\section{Kavramsal Çerçeve}

Finansal tablo manipülasyonun sözlük anlamı hileli yönlendirme olup, özellikle dönem karı ile ilgili bilgileri yanlış yönlendirmek için gelir tablosu kalemleri ile işletmenin finansal yapısına ilişkin bilgilerin yanlış yorumlanmasına neden olacak şekilde bilanço kalemleri üzerinde yapılan faaliyetleri kapsamaktadır. Finansal tablo manipülasyonu denince kazanç yönetimi, gelir düzeltme, yaratıcı muhasebe, ve vitrin süsleme gibi kavramları bağdaştırmaktadır. Bu kavramların her biri ise finansal tablo manipülasyonunun farklı bir yönünü açıklamaktadırlar (Varıcı ve Er, 2013: 43-44).

Finansal raporlar, işletmenin gelecekteki nakit akışlarının belirlenmesinde ve işletmenin satın alma ve birleşme kararlarında yatıımcılara önemli bilgi sağlamaktadır. Ancak, finansal raporlama sürecinde, muhasebe politikalarının tercihli olarak sunulması firmaları manipülasyona ittiği düşünülebilir (Dye, 2002: 
1126). Çalışmada finansal raporlama sürecinde, finansal tablo manipülasyonunun ulusal genel kabul görmüş muhasebe ilkelerine göre veya uluslararası finansal raporlama standartlarına göre olmasının farklı olduğunu düşünmekteyiz.

2002'de Amerika Birleşik Devletlerinde, finansal raporlama sürecindeki hata ve hileler ile Enron, World Com, Tyco, Imclone, Adelphia, Global Crossing gibi büyük şirketlerde ortaya çıkan yüksek profilli kurumsal başarısızıklar sonucunda, ülkedeki kurumsal yönetim uygulamalarını iyileştirmek amacıyla 1934 yılındaki Menkul Kıymetler Kanunu'ndan (Securities Exchange Act) beri kapsamlı çözümler içeren kurumsal yönetim ilkelerinin önemi Sarbanes-Oxley kanunu ile ortaya konmuştur (Song ve Thakor, 2006). Defter kayıtlarındaki hile ile ilişkili olan bu sözü edilen büyük skandallar, hisse senedi piyasalarının çökmesine ve kurumsal sektörlerin varlık kazanmasına neden olmuştur. Bu skandalları önlemek için başarısız olan yönetimler kurumsal yönetim mekanizmalarını yaygınlaştırmışlardır (Benz ve Frey, 2007). Böylece, kurumsal yönetimde gelişme, Sarbanes-Oxley Kanunu'nda belirtildiği gibi ve kurumsal yönetim sistemlerinde ileri gelişmeleri dikkate alan düzenlemeler aranmaya başlamasıdır.

Kurumsal yönetim mekanizması, finansal raporlamanın güvenirliliğini etkileyen önemli unsurdur. Ayrıca, kurumsal yönetim mekanizmaları, finansal raporlama sisteminin kalitesini ve muhasebe uygulamalarını da etkilemektedir (Anderson vd., 2004). Kurumsal yönetimde IFRS'nin rolü, şirketin performansını değerlemek ve şirket yöneticilerine gerekli finansal bilgiyi sağlamasıdır (Drever vd., 2007). Kurumsal yönetim; kamuya açıklama, şeffafıı, hissedar değerini dikkate alan, uluslararası örgütler, akademisyenler, yatırımcılar, şirket ortakları, yöneticiler, endüstri operatörleri, devlet ve diğer paydaşların geniş katılımıyla ortaya konulan artan cazibeyle ilgi oluşturan yeni bir alan çalışmadır. Dünya Bankası (WB), Uluslararası Para Fonu (IMF) ve Ekonomik İş Birliği ve Gelişme Örgütü (OECD) gibi kurumlara göre de, kurumsal yönetim; sürdürülebilir ekonomik gelişmeyi teşvik etmek, yatırımcı güveninin yeniden kazanılmasının ve piyasalarda rekabeti düzenlemeye yardımcı olan unsurlar olarak konulan ilkeleri kapsamaktadır. Kurumsallaşmanın ilkeleri; sorumluluk ve şeffaflık, dürüstlük, doğruluk ve eşitlik, hesap verilebilirlik, ehliyet ve itibar olarak gruplanmaktadır (Inyang, 2009: 1-3).

Kurumsal yönetim uygulamaları, şirketten finansal bilgi almayı amaçlayan tüm paydaşların geniş katılımını sağlayan, muhasebe standartları ve finansal raporlama standartlarının uygulanmasını zorunlu kılarak, finansal raporlamanın güvenirliğinin arttırılmasına katkı sağlamaktadır. İşletmeler, güvenilir finansal bilgiyi paydaşlarına hazırlamış oldukları finansal raporlama ve finansal tablolar aracılı̆ııla sunmaktadır. Finansal bilgiye güvenirlilik özelliği yansıtmanın yolu kurumsal yönetim ilkelerinin benimsenerek uygulanmasından geçmektedir. Ayrıca, kurumsallaşma, yönetim ilkeleri ve temel esasları ile işletmelerin yönetim yapılarını esas alan unsurları kapsadığı gibi, işletmelerin finansal raporlamasını da dikkate alan uluslararası anlamdaki zorunlu düzenlemeleri de içermelidir.

İ̧letmelerin finansal raporlama sistemlerindeki farklılık, küresel sermaye piyasalarının etkinliğini, uluslararası ticaretin gelişimini (Shim ve Siegel, 1999: 320) ve dolayısıyla işletmelerin kurumsallaşmasını da engellemiştir. Ayrıca, ulusal finansal raporlama standartlarına göre düzenlenen finansal tablolar, yatırımcıların ve finansal tablo düzenleyicilerinin finansal tablolarının şeffaflığını ve güvenilir biçimde raporlanmasını güçleştirdiğinden (Nolke, 2005: 5), tüm dünyada kabul gören ve ortak olarak kullanılan bir finansal raporlama setine geçilmiştir. Çünkü, muhasebe sistemlerinin farklı olması, farklı muhasebe standartlarının kullanılarak şirketlerin finansal bilgilerini karşılaştırmada ve bu bilgilerin güvenilir şekilde raporlanmasında tekdüzeni engellemektedir.

İşletmelerin muhasebe sistemlerindeki farklılık, yayınlanan finansal tablolardaki finansal bilginin karşılaştırılabilirliğini ve güvenirliliğini engellemesi, muhasebe standartlarının uyumunu (Alexander, Britton ve Jorissen, 2009: 20) gerekli kılmıştır. Böylece, muhasebe standartlarında uyum kurumsal yönetim ilkelerinden şeffaflık ilkesi gereği, finansal bilginin paydaşlar için finansal tabloların anlaşılabilirliğini ve karşılaştırılabilirliğini artırabilir.

Kurumsal yönetimin en önemli fonksiyonu finansal raporlama sürecinin kaliteli olmasını sağlamaktır. Finansal raporlama sürecinin kalitesinin artması, muhasebe bilgilerinin kalitesinin de artması sonucunu doğuracaktır. Yapılan ampirik çalışmaların bazılarında, işletmelerde kurumsal yönetim kalitesi arttıkça, 
gelecekte elde edilecek gelirlere ilişkin finansal bilgilerin kalitesinin de arttığı sonucuna varılmıştır. Bazı çalışmalarda ise, kurumsal yönetim mekanizmasının muhasebe bilgi kalitesini arttırdığını ortaya koymuştur. Ancak, kurumsal yönetimle ilgili tüm düzenlemelere ve gelişmelere bağlı olarak, günümüzde yöneticiler hala kazançları yönetme veya kötü haberleri gizleme doğrultusunda eğilim gösterebilmektedir. Bazı yöneticiler için finansal tablolardan elde edilen finansal raporlama, servetlerini maksimize etme stratejilerinin anahtar bileşeni olarak rol üstlenmektedir (Gençoğlu Gücenme ve Ertan, 2012: 18-19). Kurumsallaşma, yönetim ilkeleri ve temel esasları ile işletmelerin yönetim yapılarını esas alan unsurları kapsadığı gibi, işletmelerin finansal raporlamasını da dikkate alan uluslararası anlamdaki zorunlu düzenlemeleri de içermelidir.

Kurumsal yönetim aynı zamanda, iş ahlaki çerçevesinde işletme faaliyetlerinin şekillendirmesini de kapsamaktadır. Bu noktada iş ahlakı; bir işletmenin işletme politikaları, ilkeleri, prosedürleri ve toplu sözleşmelerini müteakiben kurumsal yönetim unsurlarının ayrılmaz parçası olarak önem arz edecektir (Terblanche vd., 2008: 246). Görüldüğü gibi kurumsal yönetim uygulamaları, şirketten finansal bilgi almayı amaçlayan tüm paydaşların geniş katılımını sağlayan, muhasebe standartları ve finansal raporlama standartlarının uygulanmasını zorunlu kılarak, finansal raporlamanın güvenirliğinin arttırılmasına katkı sağlamaktadır. İşletmeler, paydaşlarına güvenilir finansal bilgiyi, hazırladıkları finansal raporlama ve finansal tablolar aracılığıyla sunmaktadır. Finansal bilgiye ilişkin olarak güvenirlilik özelliği ise kurumsal yönetim ilkelerinin benimsenerek uygulanmasından geçmektedir. Bu bağlamda bakıldığında kurumsal yönetim ilkelerini benimseyen şirketlerin sundukları finansal bilgiler de bu özellikleri taşıyacakları için finansal raporlamanın güvenirlikleri arttırımış olacaktır.

Finansal raporlama süreci işletme yöneticilerinin davranışlarından etkilenmiyorsa, işletmelerde hissedarların hesap verme sorumluluğu azalmaktadır. Buna karşılık, sosyal raporlamada hesap verme sorumluluğu nötr olsa bile, hesap verebilme anlamında sorumluluğun tamamen etkisinden kurtulma problemi hala devam edecektir (Hess, 2007: 457). Kurumsal performansın sorumluluğu, hissedar değeri ve finansal raporlamanın güvenirliliğini artırmaktadır. Ayrıca, işletme yöneticilerinin finansal tabloların hazırlanma sürecinde doğru ve güvenilir bilgi sunma sorumluluğunu taşıyamaması veya finansal raporlama sürecinin kaliteli yapılmasına engel olma tutumlarının önlenememesi finansal tabloların güvenirliğini azaltmaktadır (Rezaee, 2002). Bu durumda, finansal tablolardaki aşırı hile muhasebe hesaplarında kullanılan raporlamanın öngörüsünde yetersizliğe yol açmaktadır. Ön araştırmalarda dikkate alınmayan bu tür hile riski, hatta kavramsal çerçevede ve finansal raporlamada yanıltıcı önemli artışa yol açacaktır. Finansal raporlamadaki güvenirlilik ve anlamlılık, raporlanan hesapların güvenirliği ile ilgilidir. Bu hesaplar, finansal tabloları düzenleyenlerin ön yargılarından bağımsız olmadıkça ekonomik realiteyi yansıtamaz (Smieliauskas, 2008). Böylece, finansal raporlamadaki kamuoyunu aydınlatma tarafsızlığını desteklemek için finansal tablo kalemlerinin gerçekçi düzenlenmesi ve yanıltıcı bilgiye dayalı hile riskini azaltmak gerekir.

İşletmenin kötü yönetilmesi ya da yanlış işletme kararlarının alınması işletmenin iflasına neden olsa bile, bu tür durumlar bir suç unsuru olarak adlandırılamaz. Ancak, finansal tabloların yöneticiler tarafından bilerek yanlış raporlanması bir suç unsuru olarak atfedilmektedir (Ball, 2009). Dolayısıyla, muhasebeciler, avukatlar, bağımsız direktörler ve şirketleri yöneten diğer profesyoneller, şirket kültüründeki etik davranışların yönlendirilmesinde ve finansal raporlama sürecinde çok önemli rol oynamaktadırlar (Harshbarger ve Jois, 2007). Uluslararası şirketler, faaliyet gösterdikleri ilgili ülkelerde muhasebe standartları ile uyumlu finansal tablo hazırlamak zorunda olduklarından, yöneticiler işletmenin finansal raporlarının düzenlenmesinde etik davranışlardan, muhasebenin doğruluk ve dürüstlük ilkesinden aykırı davranışlarda bulunuyorlarsa, finansal manipülasyona teşvik ortaya çıkacaktır. Bu durum ise, finansal tablolara olan güvenirliği azaltacaktır.

Finansal tablo manipülasyonlarının finansal raporlarının güvenirliliğini azaltması, finansal raporlamanın daha güvenilir olması bağlamında işletme yönetimin kurumsal yönetim ilkelerini benimseme zorunluluğunu ortaya çıkarmıştır. Ayrıca kurumsal yönetim, işletmenin finansal tablolarındaki bilgilerin güvenilirliğini artıracağından, çalışmada, kurumsal yönetimin söz konusu finansal tabloların IFRS uyumuna etkisinin olacağı düşüncesinin geçerliliğini tespit etmek amaçlanmıştır. Çalışmada, finansal tablo manipülasyonu ile IFRS uyumu arasındaki ilişki incelenecektir. Bu ilişkinin belirlenmesinde Amerika'da borsaya kayıtlı banka işletmelerinin finansal verilerinden yararlanılmıştır. 


\section{Literatür ve Araştırma Hipotezlerinin Gelişimi}

\subsection{Illgili Literatür}

Uluslararası Finansal Raporlama Kurulu (IASB), IFRS'e geçiş ile finansal raporlamada yüksek kalite ve işletmelerin finansal analizinde karşılaştırmalarda üstünlük sağlamayı amaçlarken, Ball vd. (2003) ulusal muhasebe standardından daha kaliteli bir standarda gerek olmadığını ifade etmiştir. Ayrıca, Ding vd. (2007)'e göre ise yüksek kaliteli finansal raporlama standardı olarak adlandırılan IFRS'ın finansal raporlamada yüksek kaliteyi garanti etmediğini belirtmişlerdir. Dolayısıyla, ülkeler IFRS'ye zorunlu geçiş yapsalar bile, finansal raporlama sisteminde ülkeler bazı değişiklikler yapabilirler. Üstelik bu değişiklikler ülkelerin yasal ve kurumsal sisteminden (Christensen vd., 2013), finansman, vergi ve hukuk sistemi dahil özellikle ulusal faktörlerden kaynaklanabilir (Ball, 2006).

Bushman vd. (2004) çalışmalarında, ulusal genel kabul görmüş muhasebe ilkelerine göre düzenlenen işletmelerin finansal tablolarından yararlanan paydaşları bilgilendirmede yetersiz kalması ve finansal muhasebe sistemlerine ilişkin kurumsal şeffaflı̆̆ı sınırlayan iki faktörü işletme türü ve örgütsel çeşitlilik açısından incelemişlerdir. latridis (2010) çalışmasında, işletmelerin finansal analizinde IFRS' na uyumun etkisini ele alarak, IFRS' ye uyumun işletmenin finansal performansı ve pozisyonunu doğrudan etkilediği sonucuna varmıştır. Bhattacharjee ve Hossain (2010) çalışmalarında, finansal raporlamanın muhasebe kalitesini etkileyen faktörlerin, muhasebe standartlarını uygulayan ülkenin yasal ve politik kurallarına bağı olduğu ve böylece işletmenin kurumsallığı, sahiplik yapısı, sermaye yapısı, piyasa ve yasal güç ile ilişkili olduğunu ortaya koymuşlardır.

Muhasebe ve finans literatüründe geçmişte yapılan çalışmalar finansal bilgi manipülasyonunu; bazı kişisel ya da kurumsal amaçlarla finansal raporlama sürecine müdahale edilerek, kamuya açıklanacak finansal bilgilerin değiştirilmesi olarak tanımlamaktadır. Bazı muhasebe manipülasyonları, muhasebe ilkeleri ve standartlarının sağladıkları esnekliklerden faydalanarak finansal bilgi kullanıcılarının işletme performansı ve işletmenin finansal yapısı hakkındaki algılarını etkilemeye yöneliktir (Holt ve Eccles, 2003: 326-332).

Muhasebe ve finansal raporlama alanında yapılan birçok çalışma; muhasebe ölçümleri ve finansal tablolara ilişkin dipnot açıklama gerekliliklerini (Ashbaugh ve Pincus, 2001), IFRS'nın zorunlu uyumunda piyasa sonuçlarını (Hail, 2011; Daske vd., 2008; Hung ve Subramanyam, 2007), yerel GAAP'dan IFRS'ye geçiş öncesinde ve sonrasında $A B$ şirketlerinin muhasebe davranışlarını (Landsman vd., 2012; Tsalavoutas vd., 2012;) incelemiştir. Ayrıca, literatürde bazı çalışmalar ulusal muhasebe standartlarından IFRS'ye geçişte muhasebe kalitesinde değişiklik olup olmadığını incelerken (Ajinkya vd., 2005; Kent ve Stewart, 2008), bir kısım çalışmalar ise yönetim kazanç tahminlerine göre finansal raporlama kalitesi (Karamanou ve Vafeas, 2005; Imhoff, 2003) ve bağımsız denetimden geçmiş finansal raporlama (Ball vd., 2012) ile sınırlandırılmıştır.

Literatürdeki finansal tablo manipülasyonu konusunda yapılan çalışmalardan birinci grubu denetim komitesinin varlığı ile finansal tablo manipülasyonu arasındaki ilişki oluşturmaktadır. Örnek olarak, Beasley (1996) denetim komitesinin varlığının finansal tablo hilelerini etkileme olasılıkları ile önemli ilişki olmadığını ortaya koymuştur. Araştırmanın sonuçlarına göre, denetim komitesinin varlı̆ıından ziyade yönetim kurulunun teşekkülü olarak kurumsal yönetim yapısı, finansal tablo hata ve suçlarının azaltılmasında önemli rol oynamaktadır.

Finansal tablo manipülasyonu konusunda yapılan çalışmalardan ikinci grubu hisse senedi getirileri ile finansal tablo manipülasyonu arasındaki ilişki oluşturmaktadır. Palmrose vd. (2004) çalışmalarında, finansal tablolardaki manipülasyon işlemlerinin hisse senedi fiyatlarında aşırı düşüşe yol açtığını incelemişlerdir. Farber (2005) çalışmasında finansal tablo manipülasyonu olan firmaların kontrol firmalarına oranla daha düşük kurumsalık göstergelerine sahip olduğunu ortaya koymuştur. Xu vd. (2006) çalışmalarında, finansal tablo manipülasyonu olan firmalarda negatif anormal getiriler olduğunu bulmuşlardır.

Finansal tablo manipülasyonu konusunda yapılan çalışmalardan üçüncü grubu ise CEO teşviklerinin manipülasyonu artırıp artırmadığı hususudur. Örneğin, Erickson vd. (2006) CEO'ların kâr primi teşviki ile finansal tablo hileleri arasında herhangi bir ilişki bulamamıştır. Ancak, O'connor vd. (2006) CEO'ların şirket 
kârlarının artmasında hisse primi ile ödüllendirilmesinin hileli raporlamanın engellenmesine yol açtığını ortaya koymuştur. Erickson vd. (2006) çalışmalarında, muhasebe manipülasyonları ile hisse teşvikleri arasında istatistiki olarak ilişki olmadığı sonucuna varmışlardır. Johnson vd. (2009) çalışmalarında, finansal tablo manipülasyonu olan firmalarda satışların büyümesi manipülasyon öncesine oranla yüksek olduğunu saptamışlardır. Armstrong vd. (2009) muhasebe manipülasyonları ile CEO teşvik primleri arasında pozitif bir ilişki olmadığını bulmuştur. Agoglia vd. (2011), çalışmalarında Amerika'daki muhasebe skandalları sonucunda, kurumsal yönetim kapsamında denetim komitesinin rolündeki değişme ile finansal raporlama sisteminde kural bazlı muhasebe yerine ilke bazlı muhasebe anlayışına yönelme ve finansal tablo düzenleyicilerinin bireysel tutumlarına yönelik raporlama yapmalarını kısıtlamasına yol açtığına yer vermişlerdir. Khanna vd. (2015) çalışmalarında ise, muhasebe manipülasyonu olan işletmelerde hisse opsiyonu ile finansal tablolarda yanlış yapma olasılığı arasında anlamlı ilişki olduğunu gözlemlemişlerdir.

Ulusal ölçekli yapılan çalışmalar arasında Kamışlı ve Girginer (2010) çalışmalarında, aktif kârlılığı ve hisse basına defter değeri bağımsız değişkenlerinin, işlem bazlı manipülasyonun belirlenmesinde önemli rol oynadığı sonucuna varmışlardır. Küçük (2008) çalışmasında, işletmelerde yapılan muhasebe hileleri ve bunların neden olduğu ekonomik kaybın önemli boyutlara ulaşması, ticari ve ekonomik anlaşmazlıklar gibi nedenlerle yapılan hilelerin, finansal tablo kullanıcılarını yanıltmaya yönelik uygulamaların artması sonucunda, yapılan hilelerin temel finansal tablolarda raporlama açısından değerlemesini yapmıştır. Sonuçta, çalışmada finansal raporlamanın her kaleminde her çeşit hile yapılabileceğinin hiçbir zaman göz ardı edilmemesi ve güvenin denetimi engellemeyeceği ilkesinin herkes tarafından benimsenmesi gerektiği sonucuna varılmıştır.

Uçma (2010) çalışmasında, Türkiye'deki finansal bilgi manipülasyonlarında ve hileli finansal raporlamada denetçi sorumluluğunun ortaya çıkarılması ve denetçi sorumluluğundan yola çıkılarak denetim mekanizmasının önemini ortaya koymuştur. Dalğar ve Pekin (2011) çalışmalarında, kurumsal yönetim kalitesi yüksek olan şirketlerin finansal tablolarının daha güvenilir olduğunu ve iMKB Kurumsal Yönetim Endeksi'ne kayıtlı işletmelerin, finansal tablolarının manipüle edilmesini engelleyerek finansal tabloların güvenilirliğini artırdığı sonucuna varmışlardır. Varııı ve $\operatorname{Er~(2013)~çalışmalarında,~muhasebe~manipülasyonu~ile~firma~}$ performansı arasındaki ilişkiyi incelemişlerdir. Çalışmalarında muhasebe manipülasyonunda işletme performans ölçüleri araştırılmış olup, söz konusu manipülasyonda işletmenin aktif devir hızı, finansman oranı ve faaliyet kar marjının etkili olabileceği ortaya çıkmıştır.

\subsection{Araştırmanın Hipotezleri}

IFRS'ye uyum, şirketlerin uluslararası finansal tabloların karşılaştırılabilirliğini ve kurumsal şeffaflığını geliştirmek için gereklidir. Bu durum, IFRS'ye uyumda yatıımcıların korunmasını geliştirmek, onların sermaye piyasasında yabancı yatırımcının daha çok girişini sağlamak ve onların finansal bilgilerinin karşılaştırılabilirliğini, anlaşılabilirliğini ve güvenirliliğini geliştirmek için zorunludur (Lantto ve Sahlström, 2009). Böylece, finansal tablolara ilişkin raporlamanın güvenirliliği; hissedarların, ortakların, yatırımcıların ve diğer paydaşların daha doğru kararlar almalarına yardımcı olmaktadır. Dolayısıyla, işletmeyle ilgili çıkar grupları arasında bir menfaat çatışmasının bulunması durumunda, finansal raporlama sürecinde rol alan paydaşların kendi çıkarlarını önceleyecek manipülasyonlara gitme olasılıklarının olması, finansal raporlamanın güvenirliliğini azaltacaktır.

Finansal raporlamanın güvenirliliği, sermaye piyasalarının etkinliği açısından önemlidir. Finansal tablolar muhasebe prensiplerine göre doğru olarak hazırlandıklarında, yatırımcılar yatırım kararlarında doğru karar vermiş olacaklar. Ancak, yöneticiler doğru finansal raporlamanın önemine rağmen, kişisel kazançları için yanlış finansal tablo sonuçlarına teşvik edebilirler (Larcker ve Tayan, 2010).

IFRS'nın kullanımı, birçok varlık ve yükümlülüğün gerçeğe uygun değerle değerlemesini gerektirir veya buna izin verir. Örneğin, bir işletmenin sözleşmeye bağlı olarak borçlanma kredibilitesi azalmış ise, alacakıların ihtiyaçları ile tutarsız yükümlülükler ortaya çıkabilir. Bu gibi muhasebe işlemleri, sermaye yatırımcılarının ihtiyaçlarıyla tutarlı olduğu savunulmasına rağmen, finansal tablolardan kullanıcılarının ve alacaklılara sağlayacağı bilgi yararlılığı zayıflamaktadır. Bununla birlikte, IFRS genellikle bir işletmede işleme 
ilişkin yargılama ve tahminde bulunmayı gerektirdiği için, finansal tablo kullanıcıları daha az doğrulanabilir ve daha az güvenilir finansal tablolar sunmaları ve dolayısı ile finansal tablo manipülasyonu için fırsatlar sunabilirler (Florou vd., 2017; Ball vd., 2015; Ball vd., 2008).

Finansal tablolarda manipülasyon, firmanın finansal tablolarının kalitesinin düşmesine dair bir işaret olarak yorumlanmıştır ve durum genellikle olumsuz sonuçlara yol açmıştır. Literatürdeki yapılan araştırmalar, finansal tabloların manipülasyonunun, diğer etkilerin yanı sıra piyasa değerlemesindeki düşüşlerle ilişkili olduğunu göstermiştir (Palmrose vd., 2004). Healy ve Wahlen (1999), firmaların, yerel GAAP veya IFRS'de yer alan muhasebe uygulamalarını kullanarak finansal tabloları manipüle edebileceğini ifade etmektedirler. Bu bağlamda, muhasebe standartlarındaki değişikliklerin finansal bilgi sistemlerini ve süreçlerini ve böylece birçok bankanın performansını etkileyebileceğini düşünüyoruz.

Bankaların performansı, hissedarların firma değeri ile ilgili amacını nasıl başarıp başarmadığını göstermektedir. Literatürdeki yapılan çalışmalarda performans muhasebe ve piyasa değerine dayalı olarak yapılmaktadır (Aprilia, 2016: 506). Sahiplik ve kontrol ayrımı nedeniyle, hissedarlar yöneticilerini izlemek için performans bilgilerine ihtiyaç duymaktadır. Temsil teorileri, izleme yoluyla pay sahipleri, yalnızca yetenekli yöneticilerin kiralanmasını sağlamak istediğini bildirmektedir ve yöneticiler hissedar değerini en üst düzeye çıkarmak için çaba göstermektedirler. Bununla birlikte, yöneticiler performans bilgisini kendi menfaatleri için saptamada ve hatta manipüle etmede büyük takdir yetkisine sahiptir. Bilgi düzeyinin yüksek kullanılabilirliği, işletme yöneticilerinin değişken performansı değerlendirme riskini arttırır. Geçmişteki firma performansı değişken olduğunda, hissedarlar yöneticinin yeteneği hakkında kararsızdırlar ve dolayısıyla yönetim yeteneğini ölçmek ve doğru yöneticinin işe alınmasını sağlamak için yeni performans bilgisinin açıklanmasına güvenirler (Fu vd., 2017: 35).

$\mathrm{Bu}$ çalışmada finansal tablo manipülasyonu ile banka performansı ve muhasebe standartları arasındaki ilişkinin incelenmesinde işletmelerin finansal performansının ölçülmesinde aktif karılılı̆ı (ROA), öz kaynak karlılığı (ROE) ve aktif devir hızı (ATO) olmak üzere üç değişken kullanılmıştır. Söz konusu değişkenlerden ilk ikisi işletmenin karlılığını ve diğeri ise verimliliğini ölçmektedir (Mondal ve Ghosh, 2012: 518). Çalışmada bağımlı değişken olarak ROA, ROE ve ATO kullanılmış olup, burada bağımlı değişkenler aşağıdaki gibi formüle edilmiştir.

ROA: İ̧̧letmenin net karının toplam varlıkların defter değerine bölünmesiyle ölçülmektedir.

ROE: İşletmenin net karının öz kaynakların defter değerine bölünmesiyle ölçülmektedir.

ATO: İşletmenin net satışlarının toplam varlıkların defter değerine bölünmesiyle ölçülmektedir.

Bu çalışmada, bağımsız değişken olarak muhasebe standartları ve bu çalışmanın amacına yönelik olarak yapılan regresyon analizindeki kontrol değişkeni olarak da banka işletmelerinin büyüklüğünü belirleyen toplam varlıkları (Size) kullanılmıştır.

Araştırmadaki kontrol değişkenin belirlenmesinde, finansal tablo manipülasyonuna giden banka tanımlamasını ABD Genel Muhasebe Bürosu'na (2002)'deki sınıflaması dikkate alınmıştır. Bu tanımlamaya göre, muhasebe manipülasyonu; agresif muhasebe uygulamaları, karın olduğundan farklı gösterilmesi, satışların şişirilmesi, stokların olduğundan çok veya az gösterilmesi, finansal varlıkların olduğundan fazla gösterilmesi, borçların bilançoda gerçekten az gösterilmesi, finansal işlemlere ilişkin olguların kasıtlı veya kasıtsız olarak kötüye kullanımı, muhasebe kurallarının yanlış yorumlanması ve muhasebe uygulamalarındaki politika seçeneklerinin yanlış kullanılması gibi sınıflandırılmıştır. Ayrıca, finansal tablo manipülasyonuna gitmeyen bankalar ise, ABD'deki borsaya kayıtlı firmalarda manipülasyona gitmeyen Call Report'da finansal tabloları yayınlanan bankalardan seçilmiştir.

Yukarıda belirtilen araştırmanın amacı çerçevesinde araştırmayla ilgili geliştirilen hipotezleri aşağıdaki gibi belirtmek mümkündür:

$\mathbf{H} \mathbf{0}=$ Muhasebe standartları banka işletmelerinde işletme performansını ve finansal tablo manipülasyonunu etkilemektedir. 
H1= Muhasebe standartları banka işletmelerinde işletme performansını ve finansal tablo manipülasyonunu etkilememektedir.

\section{Araştırmanın Yöntemi}

Finansal tablo manipülasyonlarının finansal raporlarının güvenirliliğini azaltması, finansal raporlamanın daha güvenilir olması bağlamında işletme yönetimin kurumsal yönetim ilkelerini benimseme zorunluluğunu ortaya çıkarmıştır. Ayrıca kurumsal yönetim, işletmenin finansal tablolarındaki bilgilerin güvenilirliğini artıracağından, çalışmada, kurumsal yönetimin söz konusu finansal tabloların IFRS uyumuna etkisinin olacağı düşüncesinin geçerliliğini tespit etmek amaçlanmıştır.

Araştırmada data kaynağı olarak, Amerika'daki bankalara ilişkin finansal tablo manipülasyonuna yönelik data kaynakları, Securities Exchange Commision (SEC), Securities Class Action Clearinghouse (SCAC), Accounting and Auditing Enforcement Releases (AAERs) ve General Accounting Office (GAO) kurumlarının resmi internet sitelerinden tedarik edilmiştir. Araştırmanın sınırlandırması ise ABD'de borsaya kayıtlı olan 238 banka işletmesi ve 368 tane finansal tablo manipülasyonu olayı ile finansal raporlama standartları arasında bir ilişki olup olmadığı araştırılmasıdır. Ayrıca, araştırmada ele alınacak dönem ise 1996 ile 2014 yılları arasında 19 yıllık bilanço ve gelir tablosu verilerinden yararlanılmıştır. İşletmelerinin bilanço ve gelir tablosu verileri için de Call Report (Federal Finansal Kurumlar Teftiş Konseyinin-FFIEC finansal raporlar datası) adlı data setinden yararlanılmıştır. Çalışmada kullanılan data setine ilişkin manipülasyonlu bankaların dağıımı Tablo 1'de verilmiştir.

Tablo 1. Finansal Tablo Manipülasyonu Yapan Banka Verileri

\begin{tabular}{|c|c|c|c|}
\hline SCAC & SEC & GAO & Toplam \\
\hline 256 & 38 & 74 & $\mathbf{3 6 8}$ \\
\hline
\end{tabular}

Çalışmaya ait yapılan betimleyici istatistiki bilgiler aşağıda gösterilmiştir. Söz konusu tabloda, finansal tablo manipülasyonu olan bankalar (368 adet örnek olay) ile olmayan bankaların (596 adet kontrol grubu) ROA, ATO, ROE ve Toplam varlıklarına ilişkin bilgiler aşağıdaki gibidir. Tablo 2'e göre, yapılan gözlemlerin $\% 29,93$ 'ü manipülasyona maruz kalan bankalar, kalan \%70,07 ise manipülasyonsuz kontrol grubu bankalarını oluşturmaktadır.

Araştırmanın hipotezlerini test etmek için, regresyon analizi yapılacaktır. Araştırmaya ilişkin değişkenlerde kullanılmak üzere IFRS ile finansal tablo manipülasyonu arasında ilişki olup olmadığını belirlemek için, muhasebe standardı ve işletme performansı arasındaki ilişkiye bakılacaktır. Finansal manipülasyon ile IFRS arasındaki ilişkinin belirlenmesinde IFRS, ulusal GAAP verileriyle işletmelerin varlık yapısı ve işletme karlılık performansları ölçülecektir.

\section{Araştırmanın Bulguları}

Genel olarak, bu çalışma, kurumsal yönetim ve finansal raporlamayı ilgilendiren finansal tablo manipülasyonu konusunda literatüre katkıda bulunur. Kurumsal yönetim, şirket finansman tedarikçilerinin yatırımlarından kazanç sağlama konusunda kendilerini güvence altına almasının yollarını ele aldığından, muhasebe aslında firma performansıyla ilgili bir bilgi kaynağı olarak önemli bir rol oynamaktadır. Finansal tablolar, yöneticilerin performansıyla ilgili doğrulanabilir bir bilgi seti sunarak, muhasebe ve kurumsal yönetim arasında merkezi bir bağlantı oluşturur (Murcia, 2016: 126). 
Muhasebe Standartları Bankalarda İşletme Performansını ve Finansal Tablo Manipülasyonunu Etkiler mi?

Tablo 2. Finansal Tablo Manipülasyonu Olan ve Olmayan Bankalara İlişkin Betimleyici İstatistikler

\begin{tabular}{llccccc}
\hline Panal A: Manipülasyonlu Bankaların Performansları & N & Mean & P50 & St.dev. & Min. & Max. \\
\hline ROA & 4.266 & 0,13 & 0.85 & 7.29 & -138.2 & 9.74 \\
ATO & 4.266 & 0.46 & 1.15 & 7.40 & -138.2 & 12.08 \\
ROE & 4.266 & 7.75 & 8.49 & 217.2 & -329.8 & 14089.7 \\
\hline Panal B:Kontrol Değişkeni & & & & & & \\
\hline Toplam Varlıklar & 4.266 & 8.61 & 6905 & 3.09 & 259 & 2.070 \\
\hline Panal C: Manipülasyonsuz Bankaların Performansları & & & & & & \\
\hline ROA & 10.026 & 0,97 & 0.98 & 0.89 & -21.64 & 14.99 \\
ATO & 10.026 & 1.23 & 1.27 & 1.08 & -21.64 & 16.54 \\
ROE & 10.026 & 9.24 & 9.07 & 8.42 & -131.6 & 82.65 \\
\hline Panel D: Kontrol Değişkeni & & & & & & \\
\hline Toplam Varlıklar & 10.026 & 308.38 & 101013 & 120875 & 1.050 & 2.950 \\
\hline
\end{tabular}

Tablo 2'ye göre, finansal tablo manipülasyonu olan bankalar kontrol grubu olan finansal tablo manipülasyonu olmayan firmalara göre, ROA, ATO ve ROE değerlerinde düşüşe yol açmıştır. Dolayısıyla, finansal tablo manipülasyonu olan bankalar finansal tablo manipülasyonu olmayan bankalara göre, muhasebe standartları açısından işletme performansı karşılaştıııldığında manipülasyonlu banka işletmelerinin hem işletme karlılığı ve hem de işletme verimliliği düşmüştür. Bu bulgu Elayan vd. (2008)'ın çalışmasıyla uyumlu olup, söz konusu çalışmada finansal tablo manipülasyonu olan firmalarda kontrol grubu olan firmalara göre daha düşük performans sergilendiği gözlemlenmiştir. Sonuç olarak, betimleyici istatistiki verilere göre, finansal tablo manipülasyonu Amerika'da borsaya kayıtlı banka işletmelerinin finansal performansını olumsuz yönde etkilediğini ifade edebiliriz. Ayrıca Tablo 2'ye göre; toplam varlıkları küçük olan bankaların toplam varlıkları daha büyük bankalara oranla kıyaslandığında, hem işletme karlılığı ve hem de işletme verimliliği daha düşüktür.

Tablo 3. t-test Eşit Varyans (\%95 güven aralığında)

\begin{tabular}{lcccccc}
\hline & & US GAAP & & \multicolumn{2}{c}{ IFRS } \\
\hline Panal A: Manipülasyonlu Bankaların Performansları & $\mathbf{N}$ & Mean & $\mathbf{p}$ & $\mathbf{N}$ & Mean & $\mathbf{p}$ \\
\hline ROA & 3.996 & 0.10 & 0.11 & 270 & 0.55 & 0.08 \\
ATO & 3.996 & 0.44 & 0.12 & 270 & 0.80 & 0.10 \\
ROE & 3.996 & 7.91 & 3.54 & 270 & 5.48 & 1.02 \\
\hline Panal B:Kontrol Değişkeni & & & & & & \\
\hline Toplam Varlıklar & 4.014 & 7.01 & 0.42 & 270 & 3.23 & 3.61 \\
\hline Panal C: Manipülasyonsuz Bankaların Performansları & & & & & \\
\hline ROA & 10.026 & 0,97 & 0.008 & 4.266 & 0.13 & 0.11 \\
ATO & 10.026 & 1.23 & 0.10 & 4.266 & 0.46 & 0.11 \\
ROE & 10.026 & 9.24 & 0.84 & 4.266 & 7.75 & 3.32 \\
\hline Panel D: Kontrol Değişkeni & & & & & & 471.432 \\
\hline Toplam Varlıklar & 10.026 & 308.384 & 12.071 & 4.266 & 8.61 & 4 \\
\hline
\end{tabular}


Tablo 3'e göre, yapılan gözlemlerin manipülasyona maruz kalan bankaların muhasebe standardı bağlamında \%93,70'inin US GAAP standardını kullandığı, kalan \%6,30'u ise IFRS'ı zorunlu tercih eden bankalardır. Ayrıca, tabloda, yapılan gözlemlerden manipülasyonsuz kontrol grubunu temsil eden bankaların \%29,93'ünün muhasebe standardı olarak IFRS'i kullandıkları, kalan \% 70,07'sinin ise US GAAP'ı tercih ettikleri görülmektedir.

Tablo 3'e göre, muhasebe standartları işletmelerin hem finansal performansını hem de finansal tablo manipülasyonunu etkilediği sonucuna varılabilir. Tablo 3'e göre, finansal raporlamada IFRS'i kullanan ve manipülasyona giden bankalar US GAAP standartlarını kullanan bankalara kıyasla ROA, ATO ve ROE değerlerinin daha yüksek olduğu görülmektedir. Ayrıca, finansal raporlamada IFRS'i kullanan ve manipülasyona gitmeyen bankalarda US GAAP standartlarını kullanan bankalara kıyasla ROA, ATO ve ROE değerlerinin daha düşük olduğu görülmektedir.

Dolayısıyla, finansal tablo manipülasyonu olan bankalarda muhasebe standartları işletmelerin finansal performansının ölçülmesinde aktif karlılı̆ı (ROA) ve öz kaynak karlılı̆ı (ROE) ölçüsü olan işletme karlıı̆ını ve aktif devir hızı (ATO) olan işletme verimliliğini artırdığını ifade edebiliriz. Buna karşılık, finansal tablo manipülasyonu olmayan bankalarda muhasebe standartları açısından IFRS kullanan bankaların US GAAP standardını kullanan banka işletmelerinden hem işletme karlılığı ve hem de işletme verimliliği düşük düzeyde seyretmektedir. Söz konusu değerlendirmelere göre, "muhasebe standartları banka işletmelerinde işletme performansını ve finansal tablo manipülasyonunu etkilemektedir" HO hipotezinin kabul edilmesi gerekir.

\section{Sonuç}

Finansal piyasaların temel işlevi olan finansal bilginin, ekonomik ve işletme performansını çeşitli yollarla artırabileceği olasıdır. Bununla birlikte; kâr yönetimi, yanıltıcı finansal raporlama, yaratıcı ve agresif muhasebe uygulamaları, muhasebe hata ve usulsüzlükleri ve muhasebe ve finansal tablo manipülasyonu olarak değişik ifadelerle adlandırılan finansal bilgi manipülasyonu, ekonomide kaynak tahsisinde etkinliği ve finansal raporlamanın güvenirliliğini azaltabilir.

Finansal tablo manipülasyonları sayesinde finansal raporlarının güvenirliliğini azaltması, finansal raporlamanın daha güvenilir olması bağlamında işletme yönetimin kurumsal yönetim ilkelerini benimseme zorunluluğunu ortaya çıkarmıştır. Ayrıca kurumsal yönetim, işletmenin finansal tablolarındaki bilgilerin güvenilirliğini artırması açısından beklenen bir olgudur. Finansal tablolara ilişkin raporlamanın güvenirliliği; hissedarların, ortakların, yatırımcıların ve diğer paydaşların daha doğru kararlar almalarına yardımcı olmaktadır. İşletmeyle ilgili çıkar grupları arasında bir menfaat çatışmasının bulunması durumunda, finansal raporlama sürecinde rol alan paydaşların kendi çıkarlarını önceleyecek manipülasyonlara gitme olasılıklarının olması ve finansal manipülasyona yönelmeleri, finansal raporlamanın güvenirliliğini azaltacaktır.

Bu çalışmada, ABD'de 1996 ile 2014 yılları arasında banka işletmelerinin kullandıkları muhasebe standartları finansal tablo manipülasyonuna bağlı olarak işletme performansını etkileyip etkilemediği ele alınmıştır. Çalışmada, ABD'de finansal tablo manipülasyonu olan bankaların kontrol grubu bankalara kıyasla özellikle IFRS'nı kullanan bankaların işletme karlılı̆ı ve verimliliğinin arttırdığı ve IFRS'ı kullanıp manipülasyona gitmeyen bankalarda ise söz konusu değişkenlerin düştüğü sonucuna varılmıştır. Bu sonuçların literatürde yapılan çalışmalardan Elayan vd. (2008)'ın çalışmasıyla uyumlu olduğu gözlemlenmiştir.

Dolayısıyla, muhasebe standartları ABD'de banka işletmelerinin işletme performansını ve finansal tablo manipülasyonunu etkilemiştir. Bu çalışmada gözlemlenen sonuçlar, Türkiye'de de gerek banka işletmelerinde ve gerekse diğer işletmelerde gerçekleştirilecek araştırmalar için yol gösterici bulgular sunabileceği açıktır. Bu bulguların Türkiye'de BisT'e kayıtlı işletmelerde geçerli olup olmadığı, söz konusu endekslerde yer alan işletmelerde yapılacak araştırmalar sonucunda gözlemlenen bulgularla karşılaştırılması sonucunda görülebilecektir. Farklı endekslerde işlem gören firmalara yapılacak olan benzer çalışmalar, Türkiye Finansal Raporlama Standartlarını uygulayan işletmelere işletme performansını nasıl etkilediğini ortaya koymada önemli bir rehber olabilecektir. 


\section{Kaynaklar}

Agoglia, C. P., Doupnik, T. S., \& Tsakumis, G. T. (2011). Principles-based versus rules-based accounting standards: The influence of standard precision and audit committee strength on financial reporting decisions. The Accounting Review, 86 (3), 747-767.

Ajinkya, B., Bhoraj, S., \& Sengupta, P. (2005). The association between outside directors, institutional investors and the properties of management earnings forecasts. Journal of Accounting Research, 43(3), 343-376.

Akgün, A.i. (2011). Türkiye finansal raporlama standartları'nda şerefiye ve gerçeğe uygun değer ilişkisi. Cumhuriyet Üniversitesi iiBF Dergisi, 12(12), 39-61.

Akgün, A. İ. (2012b). Muhasebenin uluslararası harmonizasyonu ve ilke bazlı muhasebe anlayışına yöneliş. Celal Bayar Üniversitesi Yönetim ve Ekonomi Dergisi, 2, 1-16.

Akgün, A. ì. (2012), Muhasebede küreselleşmenin finansal raporlama standartlarına etkisi. Cumhuriyet Üniversitesi iiBF Dergisi, 13(1), 43-59.

Akgün, A. İ., \& Şamiloğlu, F. (2017). Küresel finansal krizin muhasebe ve değer esaslı işletme performanslarına etkisi. Business and Economics Research Journal, 8(3), 453-471.

Alexander, D., Britton, A., \& Jorissen, A. (2009). International financial reporting and analysis (Fourth Edition). United Kingdom: Cengage Learning.

American Institute of Certified Public Accountants (AICPA), (2002). Statement on auditing standards (SAS) No. 99: Consideration of fraud in a financial statement audit.

Anderson, R., Mansi, S., \& Reeb, D. (2004). Board characteristics, accounting report integrity, and the cost of debt. Journal of Accounting and Economics, 37(3), 315-342.

Aprilia, K. D. K, Rohman, A., Chariri, A., \& Ghozali, I. (2016). Credit risk and earning management mediate the relationship between cash compensation and bank performance: Evidence from Indonesia. The Social Sciences, 11(21), 50605070 .

Ashbaugh, H., \& Pincus, M. (2001). Domestic Accounting standards, international accounting standards, and the predictability of earnings. Journal of Accounting Research, 39(3), 417-434.

Baber, W. R, Kang, S-H, Liang, L., \& Zinan, Z. (2009). Shareholder rights, corporate governance, and accounting restatement. Georgetown University, Working paper. Available at: http://ssrn.com/abstract=760324.

Ball, R., Askon, R., \& Sadka, G. (2008). Is financial reporting shaped by equity markets or by debt markets? An international study of timeliness and conservatism. Review of Accounting Studies, 13(2), 168-205.

Ball, R., Li, X., \& Shivakumar, L. (2015). Contractibility and transparency of financial statement information prepared under IFRS: Evidence from debt contracts around IFRS adoption. Journal of Accounting Research, 53(5), 915963.

Ball, R. (2006). International Financial Reporting Standards (IFRS): Pros and cons for investors. Accounting and Business Research, International Accounting Policy Forum, 2006, 5-27.

Ball, R. (2009). Market \& political/regulatory perspectives on the recent accounting scandals. Journal of Accounting Research, 47(2), 277-323.

Ball, R., Jayaraman, S., \& Shivakumar, L. (2012). Audited financial reporting and voluntary disclosure as complements: A test of the confirmation hypothesis. Journal of Accounting and Economics, 53, 136-166.

Ball, R., Robin, A., \& Wu, J. S. (2003). Incentives versus standards: Properties of accounting income in four East Asian countries. Journal of Accounting and Economics, 36, 235-270.

Beasley, MS. (1996). An empirical analysis of the relation between the board of director composition and financial statement fraud. The Accounting Review, 71(4), 443-465.

Benz, M., \& Frey, BS. (2007). Corporate governance: What can we learn from public governance? Academy of Management Review, 32(1), 92-104.

Bergstresser, D., \& Philippon, T. (2006). CEO incentives and earnings management. Journal of Financial Economics, 80(3), 511-529.

Bhattacharjee, S., \& Hossaın, Md S. (2010). Determinants of financial reporting outcomes following IFRS adoptionimplications for Bangladesh. The Bangladesh Account, January-March 2010, 10-19.

Burns, N., \& Kedia, S. (2006). The impact of performance-based compensation on misreporting. Journal of Financial Economics, 79, 35-67. 
Bushman, R. M., Piotroski, J. D., \& Smith, A. J. (2004). What determines corporate transparency? Journal of Accounting Research, 42(2), 207-252.

Christensen, H. B., Hail, L., \& Leuz, C. (2013). Mandatory IFRS reporting and changes in enforcement, ECGI-Finance Working Paper No. 377/2013; The Wharton School Research Paper; Chicago Booth Research Paper No:12-12. Available at SSRN: http://ssrn.com/abstract=2017160.

Crocker, K., \& Slemrod, J. (2007). The economics of earnings manipulation and managerial compensation. The RAND Journal of Economics 38(3), 698-713.

Cuijpers, R., \& Buijink, W. (2005). Voluntary adoption of non-local GAAP in the European Union: A study of determinants and consequences. European Accounting Review, 14(3), 487-524.

Dalğar, H., \& Pekin, S. (2011). Kurumsal yönetim ile finansal tablo manipülasyonu arasındaki ilişki: iMKB kurumsal yönetim endeksinde yer alan şirketlerde bir araştırma. Mali Çözüm Dergisi, 107, 19-43.

Daske, H., Hail, L., Leuz, C., \& Verdi, R. (2008). Mandatory IFRS reporting around the World: Early evidence on the economic consequences. Journal of Accounting Research, 46, 1085-1142.

Dellaportas, S. (2013). Conversations with inmate accountants: Motivation, opportunity and the fraud triangle. Accounting Forum, 37, 29-39.

Dietrich, A., \& Wanzenried, G. (2011). Determinants of bank profitability before and during the crisis: Evidence from Switzerland. Journal of International Financial Markets. Institutions and Money, 21, 307-327.

Ding, Y., Hope, O-K., Jeanjean, T., \& Stolowy, H. (2007). Differences between domestic accounting standards and IAS: Measurement, determinants and implications. Journal of Accounting and Public Policy, 26(1), 1-38.

Drever, M., Stanton, P., \& McGowan, S. (2007). Contemporary Issues in Accounting. Australia: John Wiley \& Sons Australia.

Dutta, S., \& Gigler, F. (2002). The effect of earnings forecasts on earnings management. Journal of Accounting Research, 40(3), 631-655.

Dye, D. A. (2002). Classification manipulation and Nash accounting standards. Journal of Accounting Research, 40(4), 1125-1162.

Efendi, J., Srivastava, A., \& Swanson, E. P. (2007). Why do corporate managers misstate financial statements? The role of option compensation and other factors. Journal of Financial Economics, 85, 667-708.

Erickson, M., Hanlon, M., \& Maydew, E. L. (2006). Is there a link between executive equity incentives and accounting fraud? Journal of Accounting Research, 44(1), 113-143.

Eleyan, F. A., Li, J., \& Meyer, T. O. (2008). Accounting irregularities, management compensation structure and information asymmetry. Accountıng and Finance, 48, 741-760.

Farber, D. B. (2005). Restoring trust after fraud: Does corporate governance matter? The Accounting Review, 80(2), 539561.

Freeman, R. B. (2010). Financial crime, near crime, and chicanery in the Wall Street meltdown. Journal of Policy Modeling, 32, 690-701.

Florou, A., Kosi, U., \& Pope, P.F. (2017). Are international accounting standards more credit relevant than domestic standards? Accounting and Business Research, 47(1), 1-29.

Fu, R., Gao, F., Kim, Y.H., \& Qiu, B. (2017). Performance volatility, information availability, and disclosure reforms. Journal of Banking and Finance, 75, 35-52.

Gençoğlu Gücenme, Ü., \& Ertan, Y. (2012). Muhasebe kalitesini etkileyen faktörler ve Türkiye'deki durum. Muhasebe ve Finansman Dergisi, 53, 1-24.

Hail, L. (2011). Discussion of consequences and institutional determinants of unregulated corporate financial ftatements: Evidence from embedded value reporting. Journal of Accounting Research, 49(2), 573-594.

Harris, J., \& Bromiley, P. (2007). Incentives to Cheat: The influence of executive compensation and firm performance on financial misrepresentation. Organization Science, 18(3), 350-367.

Harshbarger, S., \& Jois, G. U. (2007). Looking back and looking forward: Sarbanes-Oxley and the future of corporate governance. Akron Law Review, 40(1), 1-53.

Hess, D. (2007). Social reporting and new governance regulation: The prospects of achieving corporate accountability through transparency. Business Ethics Quarterly, 17(3), 453-476.

Healy, P. M., \& Wahlen, J. M. (1999). A review of the earnings management literature and its implications for standard setting. Accounting Horizons, 13(4), 365-383. 
Holt, A., \& Eccles, T. (2003). Accounting practice in the post-Enron era: The implications for financial statements in the property industry. Briefings in Real Estate Finance 2(4), 326-340.

Hung, M., \& Subramanyam, K. R. (2007). Financial statement effects of adopting International Accounting Standards: The case of Germany. Review of Accounting Studies, 12, 623-657.

latridis, G. (2010). International Financial Reporting Standards and the quality of financial statement information. International Review of Financial Analysis, 19, 193-204.

Imhoff, E. A. (2003). Accounting quality, auditing and corporate governance. Accounting Horizons, 17, (Supplement), 117-28.

Inyang, B. J. (2009). Nurturing corporate governance System: The emerging trades in Nigeria. Journal of Business System, Governance and Ethics, 4(2), 1-13.

Johnson, S. A., Ryan, H.E., \& Tian, Y.S. (2009). Managerial incentives and corporate fraud: The sources of incentives matter. Review of Finance, 13, 115-145.

Karamanou, I., \& Vafeas, N. (2005). The association between corporate boards, audit committees, and management earnings forecasts: An empirical analysis. Journal of Accounting Research, 43(3), 453-486.

Khanna, V., Kim, E. H., \& Lu, Y. (2015). CEO connectedness and corporate fraud. The Journal of Finance, 70(3), 12031252.

Kamışlı, M., \& Girginer, N. (2010). İşlem bazlı manipülasyonun istatistiksel sınıflandırma analizleriyle belirlenmesi. iü İktisat Fakültesi Ekonomi ve İstatistik Dergisi, 11, 1-30.

Kent, P., \& Stewart, J. (2008). Corporate governance and disclosures on the transition to International Financial Reporting Standards. Accounting and Finance, 48, 649-671.

Küçük, i. (2008). Finansal raporlamada hile-manipülasyonlar ve önlenmesi. Marmara Üniversitesi Sosyal Bilimler Enstitüsü, Basılmamış Doktora Tezi, İstanbul

Landsman, W. R., Maydew, E. L., \& Thornock, J. R. (2012). The information content of annual earnings announcements and mandatory adoption of IFRS. Journal of Accounting and Economics, 53, 34-54.

Larcker, D. F., \& Tayan, B. (2010). Financial manipulation: Words don't lie. Stanford Closer Look Series, July 23, 1-5.

Lantto, A. M., \& Salstrom, P. (2009). Impact of International Financial Reporting Standard adoption on key financial ratios. Account and Finance, 49, 341-361.

Maggi, G., \& Rodriguez-Clare, A. (1995). Costly distortion of information in agency problems. The RAND Journal of Economics, 26(4), 675-689.

Mitra, R. K., \& Adhikary, B. K. (2017). Determinants of financial performance: Empirical evidence from the textile sector in Bangladesh. Journal of Accounting and Finance, 17(8), 110-120.

Mondal, A., \& Ghosh, S.K. (2012). Intellectual capital and financial performance of Indian banks. Journal of Intellectual Capital, 13(4), 515-530. [is pep!

Murcia, F. D. (2016). The determinants of firm-specific corporate governance arrangements, IFRS adoption, and the informativeness of accounting reports: Evidence from Brazil. Journal of International Accounting Research, 15(2), 125-128.

Nolke, A. (2005). Introduction to the special issue: The globalization of accounting standards. Business and Politics, 7(3), 2005.

O'Connor, J. P., Priem, R. L. Coombs, J. E., \& Gilley, K. M. (2006). Do CEO stock options prevent or promote fraudulent financial reporting? Academy of Management Journal, 49, 483-500.

Palmrose, Z. V., Richardsonb, V. J., \& Scholz, S. (2004). Determinants of market reactions to restatement announcements. Journal of Accounting and Economics, 37(1), 59-89.

Rezaee, Z. (2002). Financial statement fraud, prevention and detection. New York: John Wiley \&Sons.

Shim, J. K., \& Siegel, J. G. (1999). Financial Accounting (Second Edition). New York: McGraw-Hill.

Smielliaskas, W. (2008). A framework for identifying (and avoiding) fraudulent financial reporting. Accounting Perspectives/Perspectives Comptables, 7(3), 189-226.

Song, F., \& Thakor, A. V. (2006). Information control, career concerns, and corporate governance. The Journal of Finance, 61(4), 1845-1896.

Terblanche, N., Pitt, L., Nel, D., \& Wallstrom, A. (2008). Corporate governance and business ethics: Pictures of the policies. Corporate Ownership and Control, 6(2), 246-254. 


\section{A. I. Akgun}

Tsalavoutas, I., André, P., \& Evans, L. (2012). The transition to IFRS and the value relevance of financial statements in Greece. The British Accounting Review, 44(4), 262-277.

Uçma, T. (2010). Finansal bilgi manipülasyonunda ve hileli finansal raporlamada denetçi sorumluluğunun belirlenmesine yönelik yapısal eşitlik modeli (SEM) uygulaması. Dokuz Eylül Üniversitesi Sosyal Bilimler Enstitüsü, İşletme Anabilim Dalı, Basılmamış Doktora Tezi, İzmir.

Varıcı, İ., \& Er, B. (2013). Muhasebe manipülasyonu ile firma performansı arasındaki ilişki: iMKB uygulaması. Ege Akademik Bakış, 13(1), 43-52.

Watts, R. L., \& Zimmerman, J. L. (1978). Towards a positive theory of the determination of accounting standards. The Accounting Review, 53(1), 112-134.

$\mathrm{Xu}$, T., Najand, M., \& Ziegenfuss, D. (2006). Intra-industry effects of earnıngs restatements due to accountıng irregularities. Journal of Business Finance and Accounting, 33(5\&6), 696-714. 
This Page Intentionally Left Blank 